\title{
Pendugaan dan Pemetaan Habitat Pakan Alami Penyu Hijau (Chelonia mydas) di Perairan Wawonii Barat, Konawe Kepulauan
}

\author{
Estimation and Mapping of Natural Food Habitat of Green Turtle (Chelonia mydas) In \\ West Wawonii Waters, Konawe Islands \\ Muhtar $^{\left.1)^{*}\right)}$, La Sara ${ }^{2)}$, Asriyana $^{2)}$ \\ 1) Jurusan Manajemen Sumber Daya Perairan, FPIK Univ. Halu Oleo, Kendari, Indonesia \\ ${ }^{2)}$ Fakultas Perikanan dan Ilmu Kelautan Universitas Halu Oleo, Kendari, Indonesia \\ Corresponding autor*): lamuhtar51@gmail.com
}

\begin{abstract}
Information of estimation and mapping on feeding habitat of green turtle (Cheloniamydas) in the district of West Wawonii is needed to manage green turtle conservation area. This study was conducted from August to October 2016. The data collected consisted of feed habitat, frequency of turtles presents and variable of supporting data. Gathering data of feeding habitat was done using survey method consisting of density data and species composition of seagrass and macroalgae. Observations of present frequency of green turtle was done weekly at each station for a month. The observation was conducted at 08.00-17.00 PM. Environmental parameters were measured at each observation station in the same time with the observation of present frequency of green turtles. The results of study showed that the natural food of green turtle was at seagrass and macroalgae ecosystem. The habitat was characterized by the presence of seagrass and macroalgae which consitutes the food preference of green turtles namely $T$. hemprichii 280.51 stands $/ \mathrm{m}^{2}, C$. serrulata 48.29 stands $/ \mathrm{m}^{2}$, and macroalgae of $G$. arcuata 0,25 stands $/ \mathrm{m}^{2}, S$. duplicatum 0,33 stands $/ \mathrm{m}^{2}$. Turtle nesting habitat is around seagrass and macroalgae. These ecosystems are ecosystems around coral as green turtle resting place.
\end{abstract}

Keywords : habitat natural food, green turtle, Wawonii West, KonaweIslands Indonesia

\begin{abstract}
ABSTRAK
Informasi mengenai pendugaan dan pemetaan habitat pakan penyu hijau (Chelonia mydas) di Kecamatan Wawonii Barat sangat dibutuhkan untuk pengelolaan kawasan konservasi penyu. Penelitian ini dilaksanakan pada bulan Agustus-Oktober 2016. Data yang dikumpulkan meliputi data habitat pakan, frekuensi kehadiran penyu dan variabel data pendukung. Pengempulan data habitat pakan menggunkan metode survey, meliputi data kepadatan dan komposisi jenis lamun dan makroalga. Pengamatan frekuensi kehadiran penyu dilakukan setiap minggu di setiap stasiun selama satu bulan. Pengamatan frekuensi kehadiran penyu dilakukan dari pukul 08.0017.00 WITA. Parameter lingkungan diukur disetiap stasiun pengamatan bersamaan dengan pengamatan frekuensi kehadiran penyu. Hasil penelitian menunjukkan bahwa habitat pakan alami penyu hijau berada pada ekosistem lamun dan makroalga. Habitat tersebut ditandai oleh adanya jenis lamun dan makroalga yang merupakan makanan kesukaan penyu hijau yaitu T. hemprichii 280,51 tegakan $/ \mathrm{m}^{2}$, C. serrulata 48,29 tegakan $/ \mathrm{m}^{2}$, dan jenis makroalga G. arcuata 0,25 tegakan $/ \mathrm{m}^{2} S$. duplicatum 0,33 tegakan $/ \mathrm{m}^{2}$. Habitat peneluran penyu berada di sekitar ekosistem lamun dan makroalga. Di sekitar ekosistem tersebut terdapat ekosistem karang sebagai tempat peristirahatan penyu.
\end{abstract}

Kata kunci : habitat pakan alami, penyu hijau, Wawonii Bara Konawe Kepulauan Indonesia

DOI: http://dx.doi.org/10.33772/jspi.v2n2. 


\section{PENDAHULUAN}

Perairan Pulau Wawonii merupakan salah satu perairan yang memiliki sumber daya penyu di Sulawesi Tenggara Indonesia. Jenis penyu yang sering ditemukan di Perairan Pulau Wawonii adalah penyu hijau (Chelonia mydas). Sebagaimana nelayan menangkap penyu tersebut disekitar perairan pulau ini. Penyu tersebut ada yang sengaja ditangkap oleh nelayan tetapi sebagian tertangkap pada jaring ikan (by-catch). Penyu tersebut menjadi komoditas perdegangan ilegal di daerah ini atau dijual ke daerah lain. Penyu hijau di daerah ini sering ditemukan pada ekosistem lamun dan makroalga. Beberapa penelitian yang telah dilakukan menyebutkan bahwa penyu hijau adalah hewan herbivora yang makanan utamanya adalah lamun dan makroalga (Herdiawan, 2003; Limpus et al., 2005; Arthuret al., 2009; Reisser et al., 2013).

Akibat penangkapan penyu yang terus berlangsung maka populasi penyu hijau di daerah ini semakin berkurang. Tekanan populasi penyu ini semakin tinggi karena habitatnya untuk daerah pakan alami dan mencari makan akan terus berkurang. Apabila hal ini dibiarkan terus berlangsung, maka akan mempercepat laju kepunahan populasi penyu hijau di daerah ini.

Sejauh ini penelitian tentang penyu hijau telah dilakukan di beberapa lokasi yang membahas beberapa aspek, antara lainstudi tentang penetasan telur dan analisa morfometrik tukik penyu daging (La Sara, 1986); analisis habitat penyu hijau (Herdiawan, 2003); ekologi tempat mencari makan (Arthur et al., 2009), dan karakteristik biofisik habitat peneluran penyu hijau (Ridwan et al., 2017). Penelitian tentang pendugaan dan pemetaan habitat pakan alami penyu hijau belum pernah dilakukan. Oleh karena itu, penelitian ini sangat penting dilakukan di Kecamatan Wawonii Barat, Kabupaten Konawe Kepulauan.

\section{METODE PENELITIAN}

Penelitian ini dilaksanakan di perairan Wawonii Barat, Kabupaten Konawe Kepulauan (Gambar 1). Waktu penelitian dari bulan Agustus - Oktober 2016, meliputi survey lokasi, penentuan lokasi habitat pakan dan pengambilan data lapangan.

Perairan Pulau Wawonii merupakan salah satu perairan yang memiliki sumber daya penyu di Sulawesi Tenggara. Jenis penyu yang sering ditemukan di Perairan Pulau Wawonii adalah penyu hijau (Chelonia mydas). Sebagaimana nelayan menangkap penyu tersebut disekitar perairan pulau ini. Penyu tersebut ada yang sengaja ditangkap oleh nelayan tetapi sebagian tertangkap pada jaring ikan (by-catch). Penyu tersebut menjadi komoditas perdegangan ilegal di daerah ini atau dijual ke daerah lain

Penyu hijau di daerah ini sering ditemukan pada ekosistem lamun dan makroalga. Beberapa penelitian yang telah dilakukan menyebutkan bahwa penyu hijau adalah hewan herbivora yang makanan utamanya adalah lamun dan makroalga (Herdiawan, 2003; Limpus et al., 2005; Arthur et al., 2009; Reisser et al., 2013).

Akibat penangkapan penyu yang terus berlangsung maka populasi penyu hijau di daerah ini semakin berkurang. Tekanan populasi penyu ini semakin tinggi karena habitatnya untuk daerah pakan alami dan mencari makan akan terus berkurang. Apabila hal ini dibiarkan terus berlangsung, maka akan mempercepat laju kepunahan populasi penyu hijau di daerah ini.

Sejauh ini penelitian tentang penyu hijau telah dilakukan di beberapa lokasi yang membahas beberapa aspek, antara lainstudi tentang penetasan telur dan analisa morfometrik tukik penyu daging ( $\mathrm{La}$ Sara, 1986); analisis habitat penyu hijau (Herdiawan, 2003); ekologi tempat mencari makan (Arthur et al., 2009), dan karakteristik biofisik habitat peneluran penyu hijau (Ridwan et al., 2017). Penelitian tentang pendugaan dan pemetaan habitat pakan alami penyu hijau belum pernah dilakukan. Oleh karena itu, penelitian ini sangat penting dilakukan di Kecamatan Wawonii Barat, Kabupaten Konawe Kepulauan.

Penelitian ini dilaksanakan di perairan Wawonii Barat, Kabupaten Konawe Kepulauan (Gambar 1). Waktu penelitian dari bulan Agustus - Oktober 2016, meliputi survey lokasi, penentuan lokasi habitat pakan dan pengambilan data lapangan.

Pengambilan sampel lamun dan makroalga dilakukan dengan menggunakan metode transek garis. Penarikan teransek dilakukan tegak lurus garis pantai. Transek garis diletakan mulai dari daerah berbatasan antara lamun dan terumbu karang. Setiap jarak $10 \mathrm{~m}$ diletakkan transek kuadrat $(50 \mathrm{~cm}$ x 50 $\mathrm{cm}$ ) untuk menentukan jenis dan kepadatan lamun. Jenis lamun dan makroalga yang belum diketahui diambil dan dimasukkan ke dalam kantung plastik sampel lalu diberi label dan selanjutnya 
diidentifikasi di laboratorium (Azkab, 1999), sedangkan identifikasi makroalga menggunakan panduan www.algabase.com.

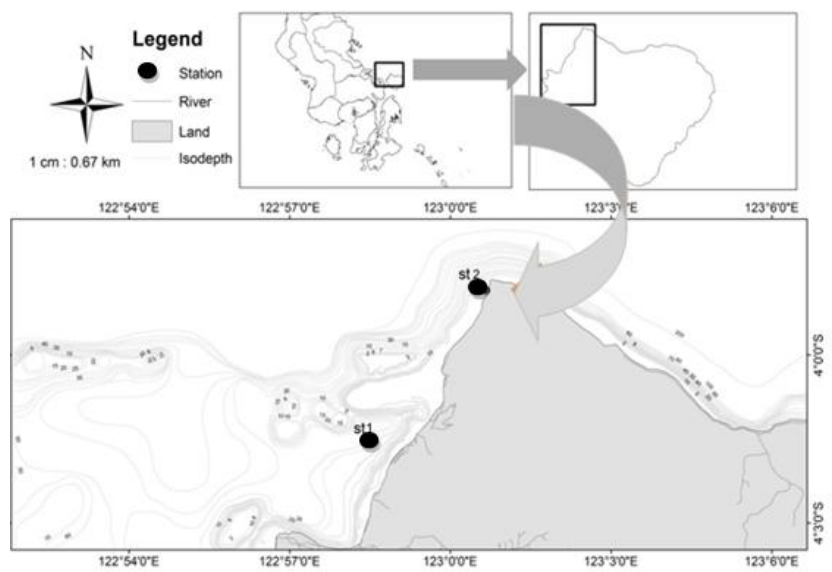

Gambar 1. Peta lokasi penelitian

Pengamatan frekuensi kehadiran penyu dilakukan setiap minggu di setiap stasiun selama satu bulan. Pengamatan frekuensi kehadiran penyu dilakukan dari pukul 08.00 sampai 17.00 WITA. Pengamatan frekuensi kehadiran mengacu pada kebiasaan makan penyu hijau yang dikemukakan oleh Bjorndal (1980) dalam penelitiannya di Union Creek, Bahama bahwa kebiasaan makan penyu hijau adalah pukul 08.00 sampai 10.00 dan 14.00 sampai 17.00 .

\section{Analisis Data}

Kepadatan lamun dan makroalga pada setiap stasiun dihitung dengan menggunakan rumus yang dikemukakan oleh Soegianto (1994) sebagai berikut : $\left.D_{i}=\frac{n i}{A} 1\right)$

\section{Keterangan :}

$\mathrm{Di}=$ kepadatan individu jenis ke-i (tegakan $\left./ \mathrm{m}^{2}\right)$

$\mathrm{ni}=$ jumlah total individu pada pengambilan contoh ke-i

$\mathrm{A}=$ luas transek $\left(\mathrm{m}^{2}\right)$

Skala kondisi kepadatan lamun pada masingmasing stasiun dihitung dengan menggunakan skala (Braun-Blanquet, 1965) yang tertera pada Tabel 1.

Tabel 1. Skala kondisi padang lamun berdasarkan kepadatan (Braun-Blanquet, 1965)

Skala Kepadatan $\quad$ Kondisi

\begin{tabular}{ccc}
\hline & $\left(\right.$ Tegakan $\left./ \mathrm{m}^{2}\right)$ & \\
\hline 5 & $>175$ & Sangat rapat \\
4 & $125-175$ & Rapat \\
3 & $75-125$ & Agak rapat \\
2 & $25-75$ & Jarang \\
1 & $<25$ & Sangat jarang \\
\hline
\end{tabular}

Indeks keanekaragaman lamun dan makrolaga dihitung dengan menggunakan rumus Indeks Brillouin dalam Soegianto (1994) yaitu:

$\mathrm{H}=\frac{(\ln \mathrm{N} !)-\left(\sum \ln n i\right)}{N}$

Keterangan :

$\mathrm{H}=$ indeks keanekaragaman

$\mathrm{ni}=$ jumlahindividuuntukjeniske- $i, i=1,2,3 . . \mathrm{n}$.

$\mathrm{N}=$ jumlahtotal individu

Frekuensi kehadiran penyu (FKP) ditentukan berdasarkan formula:

FKP $=\frac{\text { Jumlah kehadiran Penyu }}{\text { Minggu }} \times 100 \%$

Frekuensi kehadiran penyu dianalisis secara deskriptif kualitatif membandingkan setiap stasiun habitat pakan dengan stasiun lainnya. Selanjutnya data tersebut dibahas dengan menggunakan studi pustaka.

Penentuan habitat pakan alami dilakukan secara deskriptif kualitatif. Data yang dibutuhkan yaitu lamun dan makroalga yang di peroleh dari hasil Citra Satelit dan pengamatan di lapangan, frekuensi kehadiran penyu dan habitat peneluran. Kemudian peta habitat pakan alami di analisis dengan menggunakan perangkat lunak ArcMap 10.3.

\section{HASIL DAN PEMBAHASAN}

Hasil analisis kepadatan dan keanekaragaman jenis lamun di setiap stasiun penelitian masingmasing disajikan pada Tabel 2 dan 3. Data pada Tabel 2 menunjukkan bahwa kepadatan lamun tertinggi $\left(250,88\right.$ tegakan $\left./ \mathrm{m}^{2}\right)$ dan didominasi oleh jenis T. hemprichii $\left(200,71\right.$ tegakan $\left./ \mathrm{m}^{2}\right)$ terdapat pada stasiun II, sebaliknya bahwa keanekaragaman lamun tergolong rendah dan sedang masing-masing ditemukan pada stasiun I dan II.

Tabel 2. Kepadatan jenis lamun pada tiap stasiun penelitian 
Vol. 3, No. 1, 14-21, Januari 2019

\begin{tabular}{|c|c|c|c|c|c|}
\hline \multirow[b]{2}{*}{ Stasiun } & \multicolumn{5}{|c|}{ Kepadatan (tegakan/m²) } \\
\hline & \begin{tabular}{|l|} 
Enhalus \\
acoroides
\end{tabular} & $\begin{array}{l}\text { Thalassia } \\
\text { hemprichii }\end{array}$ & $\begin{array}{l}\text { Cymodoce } \\
a \\
\text { serrulata }\end{array}$ & $\begin{array}{l}\text { rata- } \\
\text { rata }\end{array}$ & Skala \\
\hline I & 0,95 & 79,81 & 0 & 80,76 & $\begin{array}{l}3=\text { agak } \\
\text { rapat }\end{array}$ \\
\hline II & 1,88 & 200,71 & 48,29 & 250,88 & $\begin{array}{l}5=\text { sang } \\
\text { at rapat }\end{array}$ \\
\hline
\end{tabular}

Tabel 3. Keanekaragaman jenis lamun pada tiap stasiun penelitian

\begin{tabular}{llcc}
\hline No & Stasiun & $\begin{array}{c}\text { Keanekarag } \\
\text { aman }\left(\mathrm{H}^{\prime}\right)\end{array}$ & $\begin{array}{c}\text { Keteran } \\
\text { gan }\end{array}$ \\
\hline 1 & I & 0,06 & Rendah \\
2 & II & 1,70 & Sedang \\
\hline
\end{tabular}

Kepadatan dan keanekaragaman jenis makroalga di setiap stasiun penelitian masing-masing menunjukkan bahwa semua stasiun penelitian memiliki kisaran kepadatan 0,25 sampai 1,78 tegakan $/ \mathrm{m}^{2}$ (Tabel 4), sedangkan keanekaragaman tergolong rendah (Tabel 5).

Tabel 4. Kepadatan jenis makroalga pada tiap stasiun penelitian

\begin{tabular}{|c|c|c|c|c|c|c|}
\hline & & $\mathrm{Ke}$ & adatar & gakan/m²) & & \\
\hline $\begin{array}{l}\text { Stasi } \\
\mathrm{n}\end{array}$ & $\begin{array}{l}\text { Padina } \\
\text { australis }\end{array}$ & $\begin{array}{l}\text { Gracilaria } \\
\text { arcuata }\end{array}$ & $\begin{array}{l}\text { Halin } \\
\text { boorr }\end{array}$ & $\begin{array}{l}\text { Sargassun } \\
\text { is duplicatu } \\
m\end{array}$ & $\begin{array}{l}\text { aChond } \\
\text { rococc } \\
\text { us hor } \\
\text { neman } \\
i\end{array}$ & $\begin{array}{l}\text { Rata- } \\
\text { rata } \\
i\end{array}$ \\
\hline I & 0,78 & 0 & 0 & 0,33 & 1,78 & 2,89 \\
\hline II & 0,83 & 0,25 & 0,46 & 0 & 0 & 1,54 \\
\hline
\end{tabular}

Tabel 5. Keanekaragaman jenis makroalga pada tiap stasiun penelitian

\begin{tabular}{llcc}
\hline No & $\begin{array}{l}\text { Stasi } \\
\text { un }\end{array}$ & $\begin{array}{c}\text { Keanekaraga } \\
\text { man (H') }\end{array}$ & Keterangan \\
\hline 1 & I & 0,78 & Rendah \\
2 & II & 0,89 & Rendah \\
\hline
\end{tabular}

Persentase frekuensi kehadiran penyu tertinggi ditemukan pada stasiun II (57 \%) dibandingkan pada stasiun I (29\%) relatif rendah (Gambar 2).
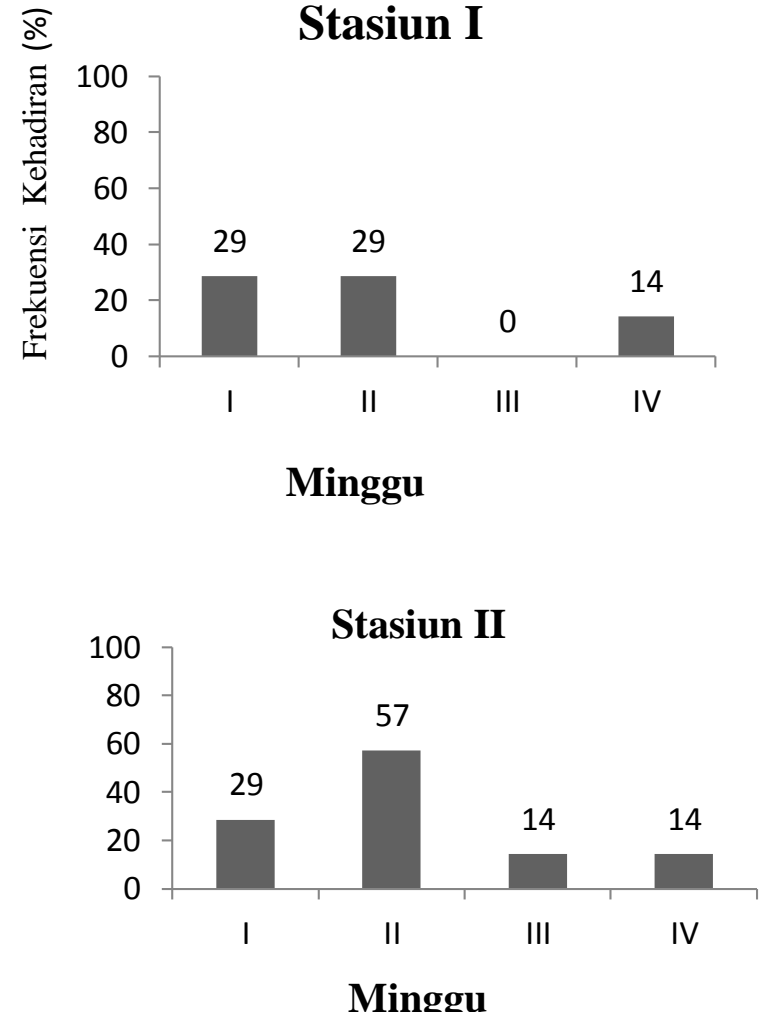

Gambar 2. Histogram frekuensi kehadiran penyu di Perairan Wawonii Barat

Hasil pengukuran parameter kualitas air (suhu, salinitas, kecepatan arus dan, kedalaman)menunjukan bahwa parameter kualitas air tersebut relatif homogen (Tabel 6).

Tabel 6. Parameter kualitas perairan berdasarkan tiap stasiun penelitian

\begin{tabular}{lllcc}
\hline No & \begin{tabular}{l} 
Parameter \\
\cline { 3 - 4 }
\end{tabular} & Kualitas Air & Satuan & \multicolumn{2}{c}{ Kisaran Nilai/ } \\
\cline { 3 - 4 } & & & \multicolumn{2}{c}{ Stasiun } \\
\hline 1 & Suhu & $\left({ }^{\circ} \mathrm{C}\right)$ & $26-31$ & II \\
2 & Salinitas & $(\mathrm{ppt})$ & $29-31$ & $29-30$ \\
5 & Kedalaman & $(\mathrm{cm})$ & $165-$ & \\
& & & 187 & $175-$ \\
& & & & 188 \\
\hline
\end{tabular}

\section{Pembahasan}

Penyu hijau memanfaatkan daerah lamun dan makroalga sebagai habitat untuk mencari makan. Iskandar (2000) menyatakan bahwa habitat penyu hijau adalah pantai yang terdapat alga dan lamun sebagai sumber makanannya. Penyu hijau adalah hewan omnivora saat masa tukik kemudian pada saat 
18 Muhtaret al.

JURNAL SAINS dan INOVASI PERIKANAN / Journal of Fishery Science and Innovation

Vol. 3, No. 1, 14-21, Januari 2019

berumur lima sampai sepuluh tahun berubah menjadi herbivora yang makanan utamanya adalah lamun dan makrolaga (Limpus et al., 2005).

Penyu hijau memilih perairan yang tidak terlalu dalam sebagai daearah untuk mencari makan. Hasil penelitian menunjukan bahwa kedalaman perairan di lokasi penelitian ini rata-rata 180 sampai $184 \mathrm{~cm}$. Kedalaman ini merupakan habitat yang dipilih penyu hijau dalam mencari makan. Bennett (1999) menyatakan bahwa kedalaman 100 sampai $155 \mathrm{~cm}$ saat pasang memudahkan penyu hijau melakukan grazing (memakan lamun atau makroalga). Selanjutnya Wibowo (2007) menyatakan bahwa habitat feeding, tempat kawin dan bertelur habitat breeding penyu hijau mudah untuk dikenali karena terletak berdekatan yaitu perairan laut dangkal dengan ekosistem lamun dan terumbu karang dan pantai berpasir putih. Ridwan et al. (2017) menyatakan bahwa lokasi habitat peneluran penyu hijau berada di Pantai Kampa Kabupaten Konawa Kepulauan. Habitat peneluran tersebut berada di lokasi pengamatan. WWW-Indonesia (2005) menyebutkan bahwa habitat penyu hijau di Indonesia dapat dijumpai di daerah pantai peneluran (nesting area) dan daerah mencari makan (feeding ground).

Selain itu, penyu hijau memilih daerah yang terdapat batu-batuan di dasar sebagai tempat peristirahatan. Berdasarkan pengamatan di lokasi kemunculan penyu berada pada daerah reef flat yang berada dekat dengan lokasi pakan penyu. Wetlands International Indonesia Programme (1996) menerangkan bahwa di perairan laut, penyu dapat dijumpai di ekosistem terumbu karang dan lamun. Penelitian yang dilakukan oleh Reisser et al. (2013) di Pulau Arvedo Brazil penyu hijau lebih memilih daerah berbatu sebagai tempat mencari makan dengan kedalaman 0 sampai $5 \mathrm{~m}$ masih terdapat makroalga yang melimpah.

Kepadatan merupakan jumlah total tegakan lamun dalam suatu unit area. Hasil penelitian menunjukkan kondisi kepadatan lamun berbeda untuk setiap jenis lamun di tiap stasiun (Tabel 4). Hal ini disebabkan oleh kemampuan adaptasi dari masing-masing jenis lamun terhadap faktor lingkungan seperti kedalaman dan jenis substrat. Jenis substrat yang relatif berpasir sangat mendukung dalam pertumbuhan dan keberadaan lamun jenis $T$. hemprichii dan C. serrulata. Nur (2004) menyatakan bahwa tingginya kepadatan jenis lamun sangat terkait dengan jumlah jenis yang ditemukan dan karekteristik habitat seperti kedalaman dan jenis substrat. Dari tiga jenis lamun yang ditemukan di lokasi penelitian, T. hemprichii mempunyai kepadatan tertinggi $\left(280,51\right.$ tegakan $\left./ \mathrm{m}^{2}\right) \mathrm{di}$ dua stasiun. Hal tersebut diduga T. hemprichii memiliki adaptasi yang baik terhadap perubahan lingkungan dan mampu tumbuh dalam kondisi tak beroksigen (anoxia) atau berkadar oksigen rendah. Romimohtarto danJuwana (2007) menyatakan bahwa T. hemprichiimampu tumbuh danberkembang dalam kondisi tak beroksigen(anoxia) atau berkadar oksigen rendah yang merupakan sifat habitat pasang surut yang dangkal sehingga mampu berkoloni dihabitat laut dangkal dengan berhasil danmengusir sebagian kelompok tumbuh-tumbuhanlainnya.

Keanekaragaman jenis lamun pada habitat pakan alami penyu berada dalam kisaran rendah sampai sedang. Kondisi tersebut berhubungan dengan jumlah jenis dan jumlah individu setiap jenis di lokasi penelitian. Jumlah individu setiap jenis yang tidak merata diduga sebagai penyebab rendahnya keanekaragaman. Yanu (2011) dalam Suryanti et al. (2014) menyatakan bahwa tinggi rendahnya nilai indeks keanekaragaman jenis dapat disebabkan oleh berbagai faktor antara lain jumlah jenis atau individu yang didapat, adanya beberapa jenis yang ditemukan dalam jumlah yang lebih melimpah daripada jenis lainnya, kondisi homogenitas substrat, dan kondisi dari ekosietem lamun sebagai habitat dari fauna perairan.

Jenis lamun yang ditemukan di tiap stasiun $(T$. hemprichii, E. acroides, danC. serrulata) merupakan jenis lamun yang dimakan oleh penyu hijau. Hal ini sesuai dengan Aragones (1999), bahwa jenis lamun yang dimakan oleh penyu hijau adalah Zostera, Thallassia, Enhalus, Posidonia, Halodule, Spyridia, Cymodecea, Halophila, dan Thalassodendron. Selanjutnya penelitian yang dilakukan oleh Herdiawan (2003) di Pantai Pengumbahan, Kabupaten Sukabumi menunjukkan bahwa jenis lamun Enhalus, Thallasia, Hallophila dan Cymodecea merupakan makanan dari penyu hijau. Berbeda dengan hasil penelitian yang dilakukan oleh Linley et al. (2007) di Moreton Australia, Halophila ovalis, Zostera capricorni, dan Cymodocea serrulata merupakan jenis lamun yang dimakan oleh penyu hijau.

Beberapa penelitian menunjukkan bahwa penyu hijau lebih menyukai jenis lamun Thallasia, Halophilla, Zostera, Cymodecea dan Halodule. 
Berdasarkan hal tersebut, maka dapat disimpulkan bahwa dari tiga jenis lamun yang ditemukan, dua diantaranya $(C$ serrulata dan $T$. hemprichi)merupakan jenis lamun yang disukai oleh penyu hijau. Arthuret al. (2009) dalam penelitianya di Shoalwater Australia menemukan bahwa di dalam lambung penyu hijau terdapat jenis lamun Halodule spp., Halophila ovalis, Zostera muelleri dan $C$. serullata.

Kesukaan penyu hijau terhadap jenis lamun $C$. serrulata dan $T$. hemprichii berkaitan dengan kandungan nutrisi dari kedua jenis lamun tersebut. Setyati et al. (2003) menyatakan bahwa lamun jenis $C$. serrulata dan $T$. hemprichii memiliki kandungan nutrisi yang cukup tinggi dibandingkan jenis $E$. acroides (Tabel 7).

Tabel 7. Hasil analisis proksimat jenis lamun menurut (Setyati et al., 2003).

\begin{tabular}{cccccc}
\hline & & \multicolumn{4}{c}{ Kandungan nutrisi (\%) } \\
\cline { 3 - 6 } No & Jenis lamun & $\begin{array}{c}\text { Prot } \\
\text { ein }\end{array}$ & $\begin{array}{c}\text { Gula } \\
\text { pared } \\
\text { uksi }\end{array}$ & $\begin{array}{c}\text { Lema } \\
\text { kabu }\end{array}$ & Serat \\
\hline 1. & T. hemprichii & 8,35 & 1,10 & 7,38 & 62,43 \\
2. & C. serullata & 9,39 & 0,91 & 7,81 & 67,09 \\
3. & E. acroides & 7,65 & 1,00 & 6,13 & 68,14 \\
\hline
\end{tabular}

Hasil penelitian menunjukan bahwa kepadatan makroalga berkisar 2,89 sampai 1,54 tegakan $/ \mathrm{m}^{2}$. Kondisi kepadatan makroalga di perairan Wawonii Barat tergolong rendah jika dibandingkan dengan kepadatan makroalga di perairan lain. Penelitian yang dilakukan oleh Nurkiama (2015), di Pulau Pacung Desa Malang Rapat Kabupaten Bintan menunjukkan kepadatan makrolaga didominasi spesies Turbinaria ornata meliliki kisaran kepadatan $\left(3,35\right.$ tegakan $\left./ \mathrm{m}^{2}\right)$. Perbedaaan kepadatan makroalga tersebut diduga oleh kondisi lingkungan yang kurang mendukung pertumbuhan dari jenis makroalga. Hal tersebut didukung oleh McNaughton dan Wolf (1990) yang menyatakan bahwa perbedaan jumlah makroalga dipengaruhi oleh beberapa faktor diantaranya daya reproduksi yang tinggi, kemampuan adaptasi dalam berkembang, daya tahan yang lemah terhadap habitat, adanya predator dan penyakit, atau keadaan lingkungan yang kurang mendukung.

Keanekaragaman jenis makroalga pada habitat pakan alami penyu berada pada kisaran yang rendah. Hal tersebut diduga disebakan oleh kondisi substrat yang relatif berpasir di tiap stasiun menyebabkan pertumbuhan makroalga terganggu. Makroalga lebih menyukai substrat yang keras sebagai tempat penempelan. Atmadja (1992) melaporkan bahwa keanekaragaman jenis makroalga pada tempat-tempat yang memiliki substrat pecahan karang mati, karang masif, dan pasir lebih stabil dan mempunyai keanekaragaman alga yang lebih tinggi dibandingkan dengan tempat-tempat yang hanya bersubsrat pasir dan lumpur.

Dari lima jenis makroalga yang ditemukan di lokasi penelitian, dua diantaranya yaitu $G$. arcuata dan $S$. duplicatum merupakan jenis makroalga yang disukai oleh penyu hijau. Hal tersebut sama dengan yang dilaporkan oleh Herdiawan (2003) bahwa jenis makroalga yang dimakan penyu hijau adalah Ulva fasciata, Caulerpa racemosa,Pterocladia sp, Gracillaria spp, Gracillaria foliifera, Sargassum sp, Turbinaria ornata,Sargassum crasifolium dan Cladophora sp. Selanjutnya Reisser et al (2013), dalam penelitianya yang dilakukan di Pulau Arvedo Brazil menemukan jenis makrolga Sargassum furcatum dan Sargassum cymosum merupakan jenis makroalga yang dimakanan penyu hijau

Frekuensi kehadiran adalah ukuran jumlah ulangan per satuan waktu dari setiap fenomena atau kejadian. Kehadiran penyu pada daerah pakan alami diduga karena adanya habitat peneluran di sekitar lokasi pengamatan. Penelitian yang dilakukan oleh Ridwan et al. (2017) menunjukan bahwa habitat peneluran penyu hijau di Pantai Kampa, Konawe Kepulauan ditandai oleh kondisi fisika dan biologi pantai yaitu suhu, kemiringan pantai, jarak pasang, lebar pantai dan vegetasi hutan pantai. Herdiawan (2003) menyatakan bahwa di daerah "inshore" daerah peneluran kadangkala ditumbuhi oleh alga dan lamun merupakan habitat yang dipilih penyu hijau.

Selain itu, kehadiran penyu hijau pada lokasi tersebut disebabkan oleh adanya jenis lamun yang merupakan makanan dari penyu hijau. Penelitian yang dilakukan oleh Blanco et al. (2012) menyatakan bahwa dari sepuluh penyu hijau yang di tandai, enam diantaranya tetap berada di perairan Kosta Rika untuk mencari makan sedangkan satu individu bergerak ke Selatan ke Teluk Panama, dan tiga penyu hijau lainnya bermigrasi ke Utara ke Perairan Teluk Fonseca di utara Nikaragua, dan satu melanjutkan pencarian makanannya ke utara ke pesisir Guatemala. Frekuensi kehadiran penyu hijau tertinggi ditemukan di stasiun II (Gambar 2). Tingginya frekuensi 
kehadiran di stasiun tersebut disebabkan oleh kondisi lingkungan stasiun II mendukung keberadaan penyu hijau. Stasiun II menyediakan sumber makanan bagi penyu hijau yaitu lamun dari jenis $T$. hemprichii $\left(200,70\right.$ tegakan $\left./ \mathrm{m}^{2}\right)$ dan $C$. serrulata $\left(48,29\right.$ tegakan $\left./ \mathrm{m}^{2}\right)$, dan makroalga jenis $G$. $\operatorname{arcuata}\left(0,25\right.$ tegakan $\left./ \mathrm{m}^{2}\right)$. Stasiun II berada tidak jauh dari lokasi peneluran $(915 \mathrm{~m})$ dibanding dengan pada stasiun I $(7.1 \mathrm{~km})$. Kondisi tersebut menyebabkan kestabilan populasi penyu hijau lebih terjamin. Richardson et al. (2009) menyatakan bahwa kondisi habitat rumput laut yang baik akan mendukung pertumbuhan penyu hijau.

Peta habitat pakan alami penyu hijau berdasarkan lokasi habitat pakan penyu, habitat peneluran, dan frekuensi kehadiran penyu hijau, tertera pada Gambar 3. Setiap lokasi habitat pakan dan habitat peneluran di buffer dan dihitung luasan area dengan menggunakan perangkat lunak ArcMap 10.3. Peta habitat pakan alami penyu hijau di buffer dengan luasan 500 meter. Berdasarkan hasil pengamatan di lokasi penelitian area $500 \mathrm{~m}$ tersebut masih berada pada daerah ekosistem lamun dan terumbu karang. Daerah tersebut masih dimanfaatkan oleh penyu hijau untuk mencari makan dan tempat beristirahat. Wetlands International Indonesia Programme (1996) menerangkan bahwa di perairan laut penyu dapat dijumpai di ekosistem terumbu karang dan lamun. Pemetaan habitat penyu sebelumnya sudah pernah dilakukan oleh Apdillah et al. (2009), di Kabupaten Bintan yang memetakan habitat peneluran, habitat pakan dan habitat Inter-breeding, dan zona kawasan habitat penyu.

Gambar 3 tersebut menunjukan bahwa lokasi habitat pakan alami dan habitat peneluran penyu berada di sekitar ekosistem lamun. Di stasiun I memiliki kepadatan lamun $\left(80,76\right.$ tegakan $\left./ \mathrm{m}^{2}\right)$ yang didominasi jenis $T$. hemprichii, sedangkan di stasiun II memiliki kepadatan $\left(250,88\right.$ tegakan $\left./ \mathrm{m}^{2}\right)$ yang di dominasi jenis T. hemprichii dan C. Serrulata. Ketiga jenis lamun tersebut merupakan makanan dari penyu hijau. Selain itu, lokasi habitat peneluran yang berada di sekitar habitat pakan alami penyu hijau dan adanya daerah berbatu disekitar lokasi pakan alami penyu hijau.

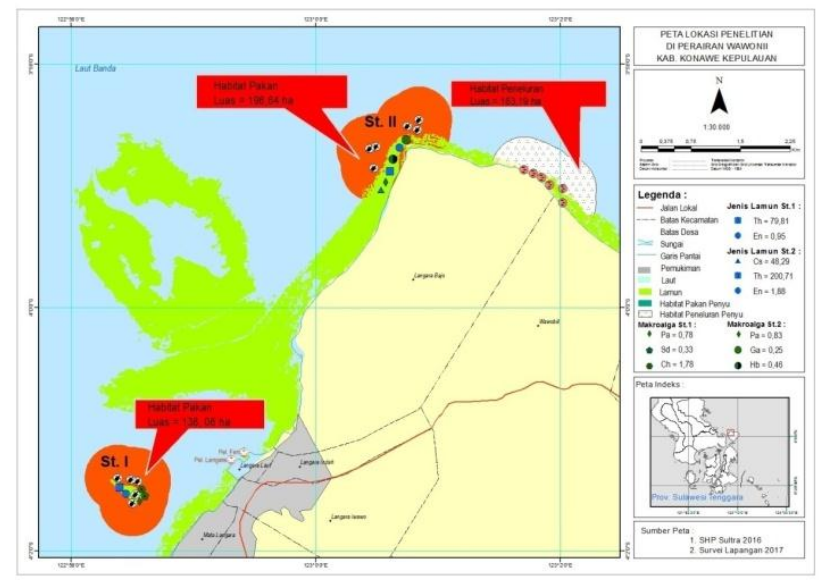

Gambar 3. Peta lokasi habitat penyu hijau

\section{KESIMPULAN}

Habitat pakan alami penyu hijau di Kecamatan Wawonii Barat Kabupaten Konawe Kepulauan berada pada habitat lamun dan makroalga. Habitat tersebut ditandai oleh jenis lamun dan makroalga yang merupakan makanan kesukaan penyu hijau yaitu T. hemprichii, $C$. serrulata, dan jenis makroalga $G$. arcuata $S$. duplicatum, habitat peneluran yang berada di lokasi pengamatan, dan adanya batu-batuan di dasar di sekitar lokasi habitat pakan alami sebagai tempat peristirahatan penyu hijau.

Berdasarkan penelitian yang dilakukan perlu diterapkan zona perlindungan di lokasi habitat pakan alami dan habiat peneluran penyu hijau untuk menjaga kelestarian penyu hijau. Selain itu perlu dilakukan upaya pemahaman kepada masyarakat dalam menjaga dan melindungi sumberdaya penyu.

\section{DAFTAR PUSTAKA}

Apdillah D, Soeharmoko, Pratomo A. 2009. Pemetaan Kawasan Habitat Penyu di Kabupaten Bintan.

Aragones LV, Marsh H. 1999. Impact of Dugong Grazing and Green Turtle Cropping on Tropical Seagrass Communities. Pacific Conservation Biology 3.

Arthur KE, McMahon KM, Limpus CJ, Dennison WC. 2009. Feeding Ecology of Green Turtles (Chelonia mydas) from Shoalwater Bay, Australia. Marine Turtle Newsletter 123:6-12. 
Atmadja WS. 1992. Rumput Laut Sebagai Obat. Oseana 17(1): 1-8.

Bennet UP, Bennett P. 1999. Aspects of Green Turtle and Hawksbill Presence in Their Feeding, Resting and Cleaning Areas off Honokowwai, West Maui, Hawaii.

Bjrndal KA. 1980. Nutrition and Grazing Behavior of The Green Turtle Cheloniamydas. Marine Biology 56: 147-154.

Blanco GS, Morreale SJ, Bailey H, Seminoff JA, Paladino FV, Spotila JR. 2012. Post-Nesting Movements and Feeding Grounds of A Resident East Pacific Green Turtle Chelonia Mydas Population From Costa Rica. Endangered Species Research 18: 233-245.

Braun-Blanquet J. 1965. Plant Sociology: The Study of Plant Communities, Trans. rev. and ed. By C.D. Fuller and H.S. Conard, Hafner, London

Herdiawan I. 2003. Analisis Habitat Penyu Hijau, Cholonia mydas Linneaus Di Pantai Pangumbahan, Kabupaten Sukabumi [Tesis]. Bogor. Program Pasca Sarjana Institut Pertanian Bogor

Iskandar DT. 2000. Kura-kura dan Buaya Indonesia dan Papua New Guinea. Bandung. Departemen Biologi Fakultas Matematika dan Pengetahuan Alam Institut Teknologi Bandung. 191 pp 56-59.

Limphus CJ, Couper PJ, Read MA. 1994. The green turtle, Chelonia mydas, in Queensland: Population Structure in a Warm Temperate Feeding Area in Memoirs of the Queensland Museum 35: 139-154

Linley MK, Johnson CR, Lanyon JM. 2007. Effects of Simulated Green Turtle Regrazing on Seagrass Abundance, Growth and Nutritional Status in Moreton Bay, south-east Queensland, Australia. Marine and Freshwater Research 58: 492-503.

Nuitja INS. 1992. Biologi dan Ekologi Pelestarian Penyu Laut. Bogor. IPB Press.

Nurkiama L, Muzahar, Idris F. 2015. Keanekaragaman dan Pola Sebaran Makroalga di Perairan Laut Pulau Pucung Desa Mala Barat Kabupaten Bintan. Jurusan Ilmu Kelautan, FIKP UMRAH.

Nur MA. 2004. Distribusi Spasial Lamun dan Kaitannya dengan Faktor Oseanografi Serta Preferensi Lamun Terhadap Susbtrat di Perairan Pulau Kondingareng Kota Makassar [Skripsi]. Makassar. Jurusan Ilmu Kelautan, Universitas Hasanuddin.
Romimohtarto K, Juwana S. 2007. Biologi Laut:Ilmu Pengetahuan tentang Biota Laut. Jakarta: Djambatan Press.

Reisser J, Proietti M, Sazima I, Kinas P, Horta P, Secchi E. 2013. Feeding Ecology of the Green Turtle (Chelonia mydas) at Rocky Reefs in Western South Atlantic.

Richardson PB, Bruford MW, Calosso MC, Campbell LM, Clerveaux W, Formia A, Godley BJ, Henderson AC, Mcclellan K, Newman S. 2009. Marine Turtles in the Turks and Caicos Islands: Remnant Rookeries, Regionally Significant Foraging Stock, and a Major Turtle Fishery. ChelonianConservation and Biology 8(2): 192-207.

Ridwan EA, La Sara, Asriyana. 2017. Telaah Karakteristik Biofisik Habitat Peneluran Penyu Hijau (Chelonia mydas) di Pantai Kampa, Konawe Kepulauan. Jurusan Manajemen Sumber Daya Perairan. Fakultas Perikanan dan Ilmu Kelautan.

Setyati, Ari W, Ridlo S, Ali. 2003. Studi Potensi berbagai Jenis Lamun sebagai Sumber Makanan Kesehatan : Analisis Proksimat.

Soegianto A. 1994. Ekologi Kuantitatif: Metode Analisis Populasi dan Komunitas. Surabaya: Usaha Nasional.

Suryanti, Ain C, Tishmawati CN. 2014. Hubungan Kerapatan Lamun (Seagrass) Dengan Kelimpahan Syngnathidae di Pulau Panggang Kepulauan Seribu. Diponegoro Journal of Maquares 3 (4):147-153.

Wetlands International-Indonesia Programme. 1996. Ekosistem Lahan Basah Indonesia. Ditjen PHKA, Wetlands International, Canada Fund, British Petroleum. Bogor. Indonesia.

Wibowo ET. 2007. Rencana Perlindungan Habitat Penyu Hijau (Chelonia mydas) (Kasus Kepulauan Derawan) [Tesis]. Bogor. Program Pasca Sarjana Institut Pertanian Bogor.

WWF-Indonesia. 2005. Indonesian Sea Turtle Conservation wwf-id@wwf.or.id-www.wwf.or.id [24 Desember 2006]. 